\title{
ENVIRONMENTAL AWARENESS AND
}

\section{THE BEST ENVIRONMENTAL PRACTICES IN SME OF THE FOOD INDUSTRY IN THE CZĘSTOCHOWA REGION}

\author{
Oksana SEROKA-STOLKA, Dorota JELONEK \\ Czestochowa University of Technology, Faculty of Management, Czestochowa, Poland
}

Caring for environmental protection through minimization of the food processing threats might turn out to be not only a complex process but it also demands a lot of expenditures. A survey carried out among small and medium-sized enterprises of the food industry in the Częstochowa region demonstrated that application of the best practices, which are environmentally friendly, is not common. It also showed that three fourth of the respondents do not implement formal environmental policies. The entrepreneurs participating in the survey exhibited a low level of environmental awareness, particularly in the area of involvement in ecological problems at the individual level.

Keywords: environmental awareness, SMEs, environmental practices, Częstochowa region, food sector

\section{Introduction}

Thefoodindustryenterprises, especially within theindividual sectors, represent a source of many threats to all the components of the natural environment: soil, water, air, plants, animals and humans. Environmental protection in the food industry should encompass almost all its resources. Rational water and wastewater management, waste management (with particular focus on the organic waste), air and soil protection from pollutants and noise protection should be a priority in implementation of the strategies that limit the negative effect of the food industry enterprises on the environment. Particular focus should be put on small and medium food enterprises which have substantial effect on the environment due to their high contribution (ca. 60\%) in the market of small and medium-sized enterprises and dominance in the private sector businesses. The share of the latter in the food production has increased from $10-15 \%$ to over $95 \%$ in recent years (Urban, 2005). SME sector generates ca. $48 \%$ of GDP in Poland. The number of active enterprises (almost $99 \%$ of the enterprises belong to SMEs) operating in the Polish market together with the number of the employees suggest, that small and medium enterprises considerably affect the conditions of the environment.

Many problems in the food industry SME sector are often caused by obsolete technologies and protective equipment. These factors cause that the food industry is considered as little environmentally friendly and are substantially responsible for its degradation. However, the food sector has been changing in recent years. Leaders have emerged in the market: to them, improper management and obsolete technologies are the future. The number of the resilient, modern and eco-minded enterprises which are properly managed is constantly increasing (Jabłońska and Kućma, 2011).

A number offactors in both external and internal enterprise environment determine the level of involvement of SME enterprises in the environmental problems. It is expressed by implementation of good environmental practices which are used, depending on the environmental awareness and attitudes of the owners/managers.

The aim of the paper is to evaluate the level of the environmental awareness among the enterprises in the SME sector in the food industry and the implementation of best environmental practices, according to the adopted model.

\section{Model of environmental practices in the enterprises of the SME sector}

Implementation of good environmental practices in the SMEs depends on a number of factors, both those originating from the external and internal environments of the enterprises. The environmental practices reflect the ecological responsibility of the enterprise and might contribute to the improvement in competitive position in the market. The latter condition is particularly important for the enterprise because in many food industry sectors, the enterprise must meet the demands of the strong competition (Simpson et al., 2004). Facilitation of the process of environmental management through implementation of the practices which are environmentally friendly leads to a number of benefits, such as effective management of the available natural resources, minimization and optimization of the environmental costs, reinforcement of the position and prestige in the market and the increased satisfaction of the customers.

Individual involvement of the managers in the enterprises of the SME sector in implementation of the environmentally friendly practices correlates with the level of their environmental awareness and attitudes (Gadenne, 2009). Environmental awareness and attitudes are stimulated by the external factors which affect the enterprises operation. These include customers, legal requirements and the expectation of the consumers, local societies and financial and state-owned institutions. Fulfilment of legal obligations by small and medium enterprises facilitates the procedures and good environmental practices (Williamson, 2006). Meeting many requirements, with a particular focus on those concerning the voluntary environmental protection in SMEs in the food industry, depends in practice on the decisions made by the entrepreneurs and managers.

Furthermore, environmental awareness of the entrepreneurs affects the implementation of the environmental management systems and the natural resources protection. However, no effect was observed in support of ecological organizations. It is only environmental attitude of the owners and managers in SMEs that correlates with the financial support of ecological organizations and initiatives in the local communities by the enterprises (Gadenne, 2009). Suppliers and consumers might both directly and indirectly stimulate implementation of the environmental practices of the SME entrepreneurs. If their environmental requirements are higher than 


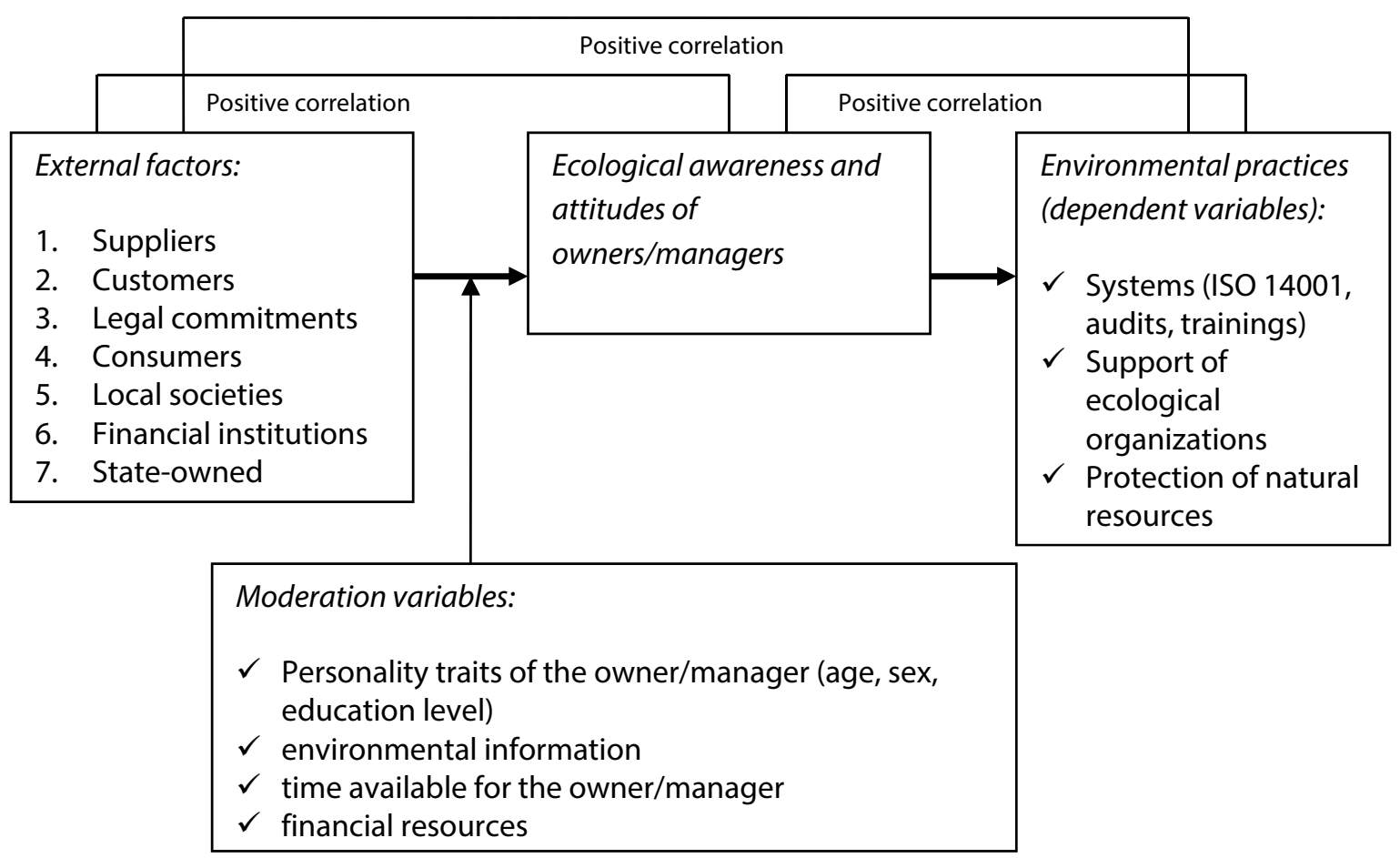

Figure 1 Model of external conditions of the environmental awareness and the environmental practices at the level of an organization (SME) Source: Seroka-Stolka, 2012

the current standards and requirements, they are a key source of ecological information and affect environmental awareness and attitudes among SME entrepreneurs (Gadenne, 2009). Environmental awareness and attitudes of managers also depend on personal traits of the owners and managers (Petts et al., 1998; Schaper, 2002). The other group of the factors, which determine application of the best environmental practices to the environment, are their financial resources, time available to the owner/manager and environmental information acquired by the entrepreneur/manager.

In order to achieve the aim of the paper, the authors investigated the factors correlated with application of good environmental practices in SMEs, according to the adopted model presented in Fig. 1.

\section{Material and Method}

In order to achieve the aim of the paper, the authors conducted a survey among 29 small (65\%) and medium (45\%) enterprises in the food industry in the Częstochowa region in Poland. The study participants were the enterprises from the sector of services $(12.5 \%)$, commerce $(18.8 \%)$, production (31.2\%) and enterprises with a mixed profile (37.5\%). In terms of the branches, the sample was dominated by the enterprises from the dairy, fruit, vegetable, bakery and meat processing industries. The most of the entities were those with national scope (53\%). The share of the enterprises in terms of the financial condition was as follows: very good (18.8\%), good (37.5\%), medium (37.4\%) and bad (6.3\%). The snowball sampling was used in the study. In the first part of the study, authors' questionnaire survey was used as a research technique. In the second part, the authors used a standard questionnaire oriented towards the owners or managers in the enterprises.

The first part of the study included questions connected with application (or planned application - if the enterprise did not use any instrument) of formal instruments of environmental management, such as ISO 14001, 14031 standards, EMAS system and informal instruments concerning educational trainings and implementation of voluntary programs to support the environmental practices in the enterprises. The owners and the managers were asked about the opportunities of investing the internal resources in technological and organizational solutions, financial support of ecological organizations and free time used for the implementation of the environmental practices which limit the negative effect the enterprise operation on the environment. The second part of the study assessed the level of environmental awareness among the managers. The analysis of the data was carried out by means of the STATISTICA 9.1 software, mainly in the quantitative and qualitative context, using the descriptive statistics.

\section{Results}

The quantitative analysis revealed that $75 \%$ of the studied small and medium enterprises do not implement the formal environmental policies of their region, whereas the effect of their operation on the environment is defined as insignificant by $52 \%$ of them. Only $6 \%$ of them assessed this effect as very big. Almost $44 \%$ of the entities, which do not have formal instruments of environmental management, do not plan implementation of ISO 14001 and ISO 14031 and over 32\% of them do not plan the implementation of the EMAS in the next three years. ISO 141001 standard is used by only $6.5 \%$ of the enterprises in the survey, whereas none of the enterprises implemented EMAS system. On average, a half of the studies enterprises are undecided about whether to implement the formal environmental instruments. Merely $7 \%$ of the enterprises in the studied sector carry out the life cycle assessment with respect to products or services (LCA). This this group included only medium-sized enterprises with good financial conditions. As much as $75 \%$ of the enterprises in the study do not organize the trainings about environmental protection and standards of social and environmental business responsibility. The enterprises are not interested in implementation of the informal environmental programmes. The respondents exhibit more interest in financial support for ecological organizations, which undoubtedly stimulates a good image and reputation of the enterprise. Financial resources 
Table 1 Distribution of the answers concerning implementation of formal and informal instruments of the environmental management in the studied enterprises

\begin{tabular}{|c|c|c|c|c|c|}
\hline $\begin{array}{l}\text { The degree to which the respondents agreed with the questions below } \\
\text { and the average score they chose for individual items }\end{array}$ & $\begin{array}{l}\text { Grouped categories: definitely } \\
\text { yes and rather yes }\end{array}$ & I do not know & $\begin{array}{c}\text { Grouped categories: definitely } \\
\text { no and rather no }\end{array}$ & $x$ & $\begin{array}{c}\text { SD } \\
N-64\end{array}$ \\
\hline Does the enterprise plan implement the ISO 14031 standard? * & $12.50 \%$ & $43.75 \%$ & $43.75 \%$ & 2.44 & 1.03 \\
\hline Does the enterprise plan implement the ISO 14001 standard? *1 & $0 \%$ & $50.00 \%$ & $43.75 \%$ & 2.56 & 1.21 \\
\hline Does the enterprise plan to implement EMAS?* & $6.25 \%$ & $62.50 \%$ & $31.25 \%$ & 2.63 & 1.02 \\
\hline $\begin{array}{l}\text { Does the enterprise implement and informal environmental program } \\
\text { in the next } 3 \text { years? }\end{array}$ & $0 \%$ & $50.00 \%$ & $50.00 \%$ & 2.31 & 0.79 \\
\hline Does the enterprise support ecological organizations financially? & $18.75 \%$ & $6.25 \%$ & $75.00 \%$ & 2.19 & 1.22 \\
\hline $\begin{array}{l}\text { Does the enterprise have its own resources used for the activities that } \\
\text { limit the effect of the enterprise on the natural environment? }\end{array}$ & $18.18 \%$ & $18.19 \%$ & $63.63 \%$ & 2.27 & 1.50 \\
\hline $\begin{array}{l}\text { Does the owner/manager have time to implement environmental } \\
\text { practices that limit the effect of the enterprise on the natural } \\
\text { environment? }\end{array}$ & $33.36 \%$ & $9.09 \%$ & $54.54 \%$ & 2.54 & 1.10 \\
\hline Does the enterprise verify the suppliers that use IS0 26000 standard? & $7.5 \%$ & $20.5 \%$ & $72 \%$ & 2.1 & 0.95 \\
\hline
\end{tabular}

Source: author's own elaboration

SD - standard deviation, - average, ${ }^{*}$ enterprises do not implement the standard or EMAS system, ${ }^{1} 6.5 \%$ of the enterprises studied implement ISO 14001 standard

and time available to a person responsible for this area is considered as an essential factor in implementation of environmental policies based on the implementation of the best environmental practices. Over $63.6 \%$ of the studied enterprises do not have sufficient financial resources that would be used for the activities that minimize the negative effect on the environment. Almost 55\% of the entrepreneurs declared that they did not have free time for inclusion of new environmental components into the system of enterprise management. The most of the studied entities do not verify the suppliers who implemented the ISO 26000 standard. The answers obtained from the respondents in the first area of research are presented in the table 1.

The second part of the study showed that the level of the environmental awareness of the entrepreneurs/managers reaches ca. $50 \%$. There is a considerable differentiation in the level of the environmental awareness in different areas.
The highest level of the environmental awareness is connected with the care for environmental aesthetics (87\%), energy savings (69\%) and water (58\%).

An opposite tendency is observed in the involvement in the ecological problems (7\%). The lowest assessment was found in the respondents' activity within the ecological organizations (2\%). Only $7 \%$ of the entrepreneurs buy the literature in the field of ecology. Few entrepreneurs choose to buy goods in glass bottles that can be reused (8.8\%) in their daily activities. Similar eco-minded tendencies are observed in transport, where driving by the employee's own cars is a standard. Almost 2\% of the entrepreneurs reported driving together to work, but carpooling organized by the enterprise for its employees is not practised. An optimistic point in the study is the fact that over $28 \%$ of the respondents collect information about the harmful effect of the chemicals they buy on the environment, while over half of the

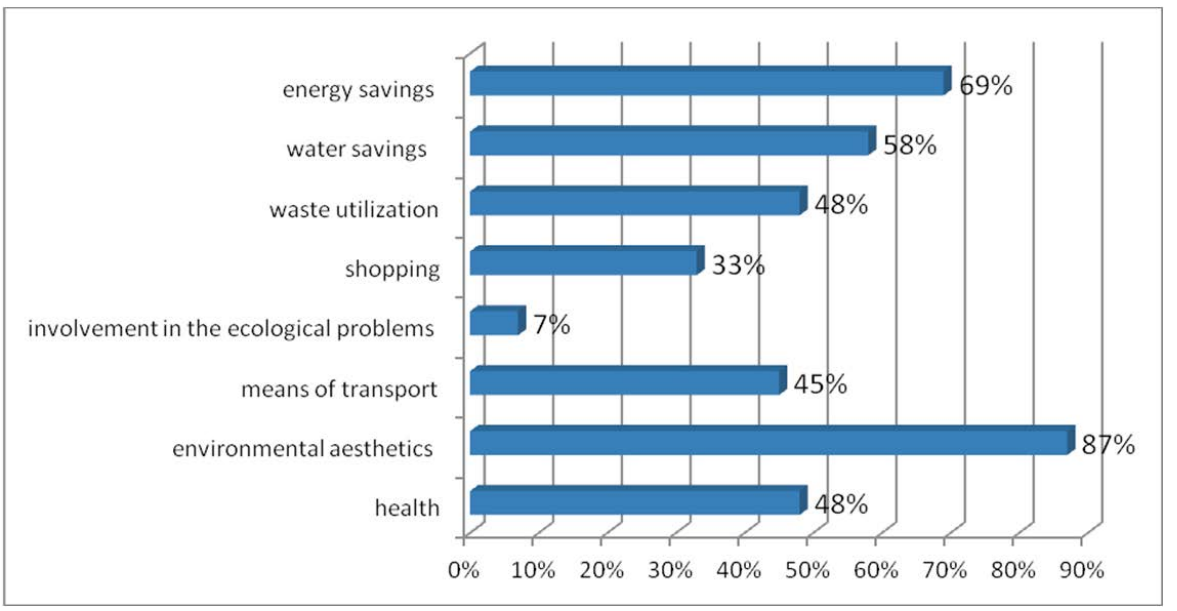

Figure 2 Level of environmental awareness among the entrepreneurs in small and medium-sized enterprises of the food industry in the analysed areas in \%

Source: author's own elaboration entrepreneurs (50.6\%) choose paper goods that originate from recycling in activities both at the level of enterprise and at the individual level.

The results of the quantitative analysis of the environmental awareness of the entrepreneurs within the studied components are represented in the figure 2 .

\section{Discussion}

The results obtained in the study lead to the conclusion that the food industry enterprises in the SME sector in the Częstochowa region are reactive rather than proactive in their attitudes connected with the problems of the environmental protection. This results from low environmental awareness of the respondents and the effect of SME enterprises on the environment. A number of previous studies in the related literature suggest that the SME sector represents a low level of environmental awareness, which is the cause of the insufficient identification of environmental threats. The study carried out by the Environmental Partnership Foundation in Poland in 2010, which was focused on the effect of small and medium-sized enterprises on the environment and determination of the degree of environmental awareness, found out that $67 \%$ of the enterprises regard the effect of the business activity as insignificant. $7 \%$ of the respondents claim that their enterprises do not impact on the environment at all and $22 \%$ of them regard the effect of their enterprises as "big and very big" (Problemy ..., 2010).

Insufficient number of financial resources and the lack of time that the managers and entrepreneurs are able to devote to the problems of environmental protection is regarded in the literature as one of the most important causes 
that make implementation of the environmental management systems impossible (Gadenne, 2009; Problemy ..., 2010).

There is little interest in the IS014001 and ISO 14031 among the respondents. In 2006, there were barely 1700 organizations with ISO 14001 in Poland (Raport). As results from the studies carried out in Poland, among the main causes of the low interest in implementation of the ISO 14001 standard compared to the ISO 9001 standard identified the entrepreneurs in particular the lack of state initiatives, including the signal that the systems of environmental management are considered to be an important instrument of implementation of ecological state policies and the principles of sustainable development (Raport). Another cause that was indicated by the enterprises is approach to the environmental problems as the secondary importance problems and the necessity of incurring very high costs compared to the benefits they derive (Potencjał).

The lack of the EMAS system implemented among the studied enterprises results from little interest in this system among the Polish entrepreneurs. In 2011, EMAS system was implemented in Poland in only 25 organizations and 32 objects (http://epp.eurostat.ec.europa.eu). The increase in the number of organizations that implement environmental management systems in Poland is minimal (http://epp.eurostat.ec.europa.eu).

The empirical study and the national-level survey demonstrated that both knowledge of the LCA methodology and the willingness of Polish small and medium enterprises to use it in practice is insufficient (Propagowanie 2006). The main causes of not using these analyses reported by the most of the enterprises were current conditions, including the lack of legal regulations. However, the respondents that participated in the study argue that the demand for these analyses can be observed and, consequently, there is the necessity of common use of LCA by the enterprises (Potencjał). The most serious limitation in all the phases of development and implementation of modern environmental technologies are financial barriers of the enterprises. These obstacles are particularly noticeable in the case of the SME enterprises which have limited financial resources and smaller opportunities of acquisition of the useful knowledge and experience than the big enterprises (Szpor et al., 2012).

\section{Conclusion}

The analyses carried out in the study demonstrated that small and medium enterprises of the food industry in the region of Częstochowa, Poland, are insignificantly active in taking formal or informal initiatives aimed at limitation of the negative effect on the environment, whereas the level of environmental awareness among the entrepreneurs is low. Implementation of ecological activities requires using new procedures, as well as implementation of innovative solutions in management and organization. It is necessary to form the organizational structures, so that they integrate environmental protection with all the environmental tasks. With growing pressure on the implementation of the instruments of voluntary character, the improvement of the environmental effects in the activities in the SME sector of the food industry should be supported by the use of informal environmental programs, which represent the first stage that impact on the increase in their eco-efficiency. The assessment of the environmental risks of the enterprise, with one of the component being the implemented system of environmental management, is one of the tools used for stimulation of ecological responsibility.

\section{References}

GADENNE, D. - KENNEDY, L. - MCKEIVER, C. J. 2009. An Empirical Study of Environmental Awareness and Practices in SMEs. In: Journal of Business Ethics, vol. 84, 2009, p. 45-63.

JABŁOŃSKA, M. - KUĆMA, M. 2011. Działanie prośrodowiskowe. Wsparcie firm branży spożywczej. Przemysł Spożywczy, 2011, no. 11.

PETTS, J. - HERD, A. - O'HEOCHA, M. 1998. Environmental responsiveness, Individuals and Organizational Learning: SME Experience. In: Journal of Environmental Planning and Management, vol. 41, 1998, no. 6, p. 711-731.

POTENCJAŁ MAŁYCH iśrednich przedsiębiorstw w dziedzinie kreowania nowych produktów innowacyjnych - rozwiązania proekologiczne, GfK, PSDB, PARP, pp. 62-64.

PROBLEMY ODDZIALYWANIA małych i średnich przedsiębiorstw na środowisko, Fundacja Partnerstwo dla Środowiska, 2010.

PROGRAM CZYSTY BIZNES. Zakopane, November 2010.

PROPAGOWANIEWZORCÓW Produkcji Konsumpcji Sprzyjających Promocji Zasad Trwałego iZrównoważonego Rozwoju, Projekt współfinansowany ze środków Unii Europejskiej oraz środków budżetowych, Program PHARE PL2003/004-379/01.0103/0s/42/13, Wykonawca projektu: Stowarzyszenie Polski Ruch Czystszej Produkcji, Projekt realizowany przy wsparciu merytorycznym Ministerstwa Gospodarki, Katowice, 2006.

RAPORT 2003-2006. Wzorce zrównoważonej produkcji i konsumpcji, Stan i rekomendacje, Ministerstwo Gospodarki, p. 47.

SCHAPER, M. 2002. Small Firms and Environmental Management: Predictors of Green Purchasing in Western Australian Pharmacies. In: International Small Business Journal, vol. 20, 2002, no. 3, p. 235-249.

SEROKA-STOLKA, 0. 2012. Czynniki implementacji dobrych praktyk środowiskowych w małych i średnich przedsiębiorstwach. In: Journal of Ecology and Health, 2012, no. 2, p. 98-103.

SIMPSON, M. - TAYLOR, N. - BARKER, K. 2004. Environmental Responsibility in SMEs: Does It Deliver Competitive Advantage? In: Business Strategy and the Environment, vol. 13, 2004, no. 3, p. 156-171.

SZPOR, A. - ŚNIEGOCKI, A. 2012. Ekoinnowacje w Polsce. Stan obecny, bariery rozwoju, możliwości wsparcia. Warsaw : Instytut Badań Strukturalnych, 2012.

URBAN, R. 2005. Polski przemysł spożywczy - konkurencyjność i szanse rozwojowe. Zagadnienia Ekonomiki Rolnej. IERiGŻ-PIB, Warszawa, 2005.

WILLIAMSON, D. - LYNCH-WOOD, D. - RAMSAY, J. 2006. Drivers of Environmental Behaviour in Manufacturing SMEs and the Implications for CSR. In: Journal of Business Ethics, vol. 67,2006, p. 317-330.

http://epp.eurostat.ec.europa.eu (AS of 10 0ctober 2012).

\section{Contact address:}

Professor Dorota Jelonek, Czestochowa University of Technology, Faculty of Management, 42-200 Czestochowa, Al. Armii Krajowej 19b, Poland, tel. +48343250846, e-mail:jelonek@zim.pcz.pl

Ph.D. Oksana Seroka-Stolka, Czestochowa University of Technology, Faculty of Management, 42-200 Czestochowa, Al. Armii Krajowej 19b, Poland, e-mail: oksanas@zim.pcz.pl 